\title{
IMPACT OF GLOBALIZATION ON HUMAN RIGHTS AND ENVIRONMENTAL PROTECTION
}

\author{
Foram A. Pandya \\ Research Scholar, \\ School of law, Gujarat University, Ahmedabad \\ Dr. Bhavesh H. Bharad \\ Assistant Professor, \\ School of law, Gujarat University, Ahmedabad
}

\begin{abstract}
Economic globalization impacts the environment and sustainable development in a wide variety of ways and through a multitude of channels. The aim of the paper is to interrogate a variety of arguments about human rights and environmental sustainability in order to assess their coherence and consistency, and to evaluate competing perspectives. The purpose of this paper is (a) to identify the key links between globalization and environment; environment and human rights An integrative section on the effects of globalization and environmental policy and performance leads to domestic and international priority policy issues and recommendations. Globalization is the process by which all peoples and communities come to experience an increasingly common economic, social and cultural environment. By definition, the process affects everybody throughout the world. In short, the more integrated environmental and trade policies are, the more sustainable economic growth will be and the more globalization can be harnessed for the benefit of the environment. The paper tries to analyze the effects of globalization and its impact on various sectors.
\end{abstract}

Key words: Environment, Globalization, Human Rights, Sustainable Development.

\section{INTRODUCTION}

All over the world, people are experiencing the effects of ecosystem decline, from water shortages to fish kills to landslides on deforested slopes. The victims of environmental degradation tend to belong to more vulnerable sectors of society, i.e., racial and ethnic minorities and the poor, who regularly carry a disproportionate burden of such abuse. Increasingly, many basic human rights are being placed at risk, as the right to health affected by contamination of resources, or the right to property and culture compromised by commercial intrusion into indigenous lands1. While the causes of the environmental degradation are contested, the ramification on the human life and realization of basic human rights are indisputable. But the international and national acknowledgement of relationship between environmental protection and human rights is relatively recent. The United Nations Conference on Environment in Stockholm in 1972 designated as the 'Magna Carta of Environment' laid down the foundation for the statutory base of the environmental law framework in India.

Environmental issues have become more important in modern economic policy. At the same time, struggle for human rights have become more complex and challenging in the era of globalization. While human rights have been increasingly protected by governments and international bodies like the United Nations, grave threats to and gross violations of human rights are also on the rise. An important issue confronting policy makers today is the complex challenge of preserving the natural environment while simultaneously promoting development to meet the basic needs of humanity. Many problems resulted in this area of discussion, with regard to the intricate linkages between globalization, human rights, and environmental decay.

So, the author discusses the inter relationship between environment and human rights and also points out the challenges to protect equitable human rights in the era of globalization in such a way that it promotes sustainable environmental development through ecofriendly trade policies. In short, by adopting the more integrated environmental policies, more sustainable economic growth will be done and globalization can be harnessed for the benefit of the environment.

\footnotetext{
${ }^{1}$ www.iisd.ca > MEA Bulletin accessed on 1.10.2019 at 12:00 pm
} 
ECONOMIC DEVELOPMENT TO ENVIRONMENTAL PROTECTION

Environmental right means access to the unspoiled natural resources that enable survival, including land, shelter, food, water and air. They also include more purely ecological rights, including the right for a certain beetle to survive or the right for an individual to enjoy an unspoiled landscape. ${ }^{2}$ The first environmental movements were a direct consequence of the industrial revolution in the late eighteenth and early nineteenth centuries; the increased use of fossil fuels and chemicals, urban expansion and deforestation and increased human consumption led to drastic changes in the environment, drastically raised the level of pollution, damaging bio-diversity and depleting natural recourses. ${ }^{3}$ The first environmental movements were, however, primarily concerned with wild- life protection and nature conservation and paid little attention to the negative effects of human settlement and commerce. It is only after the Second World War that environmental movements have become extremely active. The rise in environmental movement is closely linked to the new phenomenon of globalization, which has transformed the structure of the international system. A globalized world is one, in which the boundaries between states are less and less visible and political, economic, cultural and social events are more and more interconnected with greater and far- reaching impact. The phenomenon of globalization has led governments and individuals to realize the international and trans-boundary dimensions of environmental issues. Finally, beginning with the UN Conference on the Environment held in Stockholm, Sweden in1972 there has been an increasing movement towards the adoption of international instruments as tools for environmental protection.

\section{INTER-RELATIONSHIP BETWEEN ENVIRONMENT AND HUMAN RIGHTS}

The right to development is an inalienable human right by virtue of which every human person and all peoples are entitled to participate in, contribute to, and enjoy economic, social, cultural and political development, in which all human rights and fundamental freedoms can be fully realized. Integrating the socio-cultural, economic and environmental components is not easy. Sustainability is really a simple concept, i.e., actions taken in the present to improve the human condition and the Earth system in which we live need to be lasting and benefit future generations. Relationship between development and human rights has a long history, both in concept and in practice.

At the end of the Second World War, the most atrocious and destructive conflict humanity had ever experienced. No wonder that the founding fathers of the United Nations had pledged a strong commitment to the promotion and protection of human rights. In fact, the architecture of the United Nations, by its very Charter, is built on three main pillars: peace and security, development, and human rights. Conceptually, these three pillars were linked, interrelated and interdependent, so much so, that there could be no peace and security without development, no development without human rights and no human rights without peace and security. This trilogy was and remains the conceptual underpinning and basic mandate of the United Nations. In practice, the interrelationship between peace and security, development, and human rights has not always been evident over the years. But now days the legal protection of human rights has increasingly been invoked to achieve the ends of environment justice. Environmental justice deals with equitable utilization of resources, procedural fairness and a safe and healthy environment. In the era of globalization and a shift towards nonstate actors international human rights has acquired crucial role. It can be arguably said human right deals with the conflict between trade and the environment and provide the means to reconcile it. ${ }^{4}$ The relationship between a safe and healthy environment and human rights has been on the global agenda since the preparations for the 1972 Stockholm Conference on the Human Environment. This idea was reflected in principle 1 of the 1972 Stockholm Declaration, which states that man's natural and self-made environment is 'essential to his wellbeing and to the enjoyment of basic human rights and the right to life itself'.

Despite this strong statement, such a human rights-based argument has not been followed in subsequent environmental declarations, such as the 1992 Rio Declaration. Instead, these declarations have linked human wellbeing to the state of the environment without any explicit reference to human rights. In general, there are three broad approaches to link human rights and the environment.

1. To view a quality environment as an underlying precondition for the enjoyment of existing human rights, rather than a specific right in itself.

\footnotetext{
${ }^{2}$ http://www.foei.org/en/what-we-do/solidarity-work/environmental-rights- are-human-rights accessed on $\underline{1.10 .2019}$ at $1: 00 \mathrm{pm}$

${ }^{3}$ Environmental Movement, Encyclopedia of Sustainable Development, at http://www.ac.uk/esd/Earth/Environmental-Movement.html. accessed on 1.10.2019 at 2:00 pm

${ }^{4}$ http://www.nliu.com/new/Art8.pdf accessed on 2.10.2019 at 3:05 pm
} 


\section{GAP INTERDISCIPLINARITIES -}

An International Peer-Reviewed Open Access Journal of Interdisciplinary Studies

2. Focusing on the procedural rights of people in relation to control over their environment, such as rights to participation in environmental decision-making and access to justice.

3. A substantive justifiable right to a certain quality of environment. Provisions to this effect are found in some national constitutions, such as those of South Africa, the Russian Federation and Spain, and in the African Charter on Human and Peoples' Rights.

The link between human rights and the environment has developed in a fragmented manner across national, regional and international levels in case law, regulations and international agreements. As a result, much of the linkage between human rights and environmental law has been highlighted through decisions of national courts and regional human rights bodies. This has resulted in rapid development of jurisprudence, but the piecemeal development has lacked a comprehensive framework linking human rights and the environment.

Several efforts have sought to clarify the linkage between these important concepts at the international level. Like, a draft declaration on Principles on Human Rights and the Environment was prepared in 1994 by a group of experts, and it was presented before the UN Commission on Human Rights in 1995. This declaration proposed a substantive right to 'a secure, healthy, and ecologically sound environment' and included the concept of intergenerational equity. There are three main dimensions of the interrelationship between human rights and environmental protection:

- The environment as a pre-requisite for the enjoyment of human rights (implying that human rights obligations of States should include the duty to ensure the level of environmental protection necessary to allow the full exercise of protected rights);

- Certain human rights, especially access to information, participation in decision-making, and access to justice in environmental matters, as essential to good environmental decision-making (implying that human rights must be implemented in order to ensure environmental protection); and The right to a safe, healthy and ecologically-balanced environment as a human right in itself (this is a debated approach). ${ }^{5}$

In examining the relationship between environmental protection and human rights, the controversial question is whether environmental protection aims at enhancing the quality of human life and is thus a subset of human rights or whether environmental protection and human rights are based on different social values. Another, third approach sees human rights and environmental protection as representing two different strands with different but overlapping social values. The two strands overlap and can be mutually supportive where environmental values seek to protect human needs or well-being. However, this approach differentiates between environmental protection and human rights when the conceptual underpinnings of human rights are not suitable to address environmental issues. Further, these issues gained importance after adopting globalization as a basic mantra of the economic policies.

\section{EFFECTS OF GLOBALIZATION}

Since coming to the fore as one of the most talked-about issues of the late twentieth century and the new millennium, the phenomenon of globalization has captured world attention in various ways. Now, because of globalization's multifaceted nature, it is essential to grasp the different motivating forces that are impelling these developments aside from the purely economic, and also to recognize the different directions from which they are coming. Intrinsic to this form of globalization is a growing legal and institutional framework within which the regimes of contemporary international trade, finance and investment are being conducted. Another form of globalization has its effects on environmental and human rights struggles.

Human rights movement has long laid claim to a universalizing mission. This is evident in the assertion that the regime of rights and freedoms established through the Universal Declaration of Human Rights and the numerous other instruments that have since been promulgated in the same spirit extend beyond the arena of purely national concern. The concept of sustainable development becomes a buzz word and to implement the concept, some of the important international Conventions were entered into. The term sustainable human development may be defined as the capacity of all human communities, including the most deprived, to meet their fundamental needs for accommodation, drinking water, food, satisfactory conditions of health and hygiene, participation in decision-making, social cohesion, a social fabric, cultural and spiritual expression, etc. This entails the adaptation of technologies and lifestyles to the social, economic and environmental potential of each region, internalizing costs and establishing systems that are compatible with the biosphere. Such an approach makes sustainable human development a multifaceted process. It seeks a balance between the ecological, economic and social spheres, while also taking account of political (participation and democratization), ethical (responsibility, solidarity, social justice and sufficiency) and cultural (local diversity and artistic expression) considerations. Sustainable human development also calls for a fundamental reevaluation of our basic principles and lifestyles, and of the way our societies function, particularly regarding

\footnotetext{
${ }^{5} \mathrm{http}$ ///www.unep.org/environmentalgovernance/Events/HumanRightsandEnvironment/tabid/2046/language/enUS/Default.aspx accessed on 4.10.2019 at 4:07 pm
} 
production and consumption. This implies significant changes in attitudes and behavior, in which an awareness of living in a common space, individual responsibility for actions, and learning to identify long-term perspectives and partnership between players in different regions of the world, including governments, international institutions, business and civil society, take precedence over material factors.

\section{CONCLUSION}

With the above discussions, the author concludes that an important issue confronting policy maker today is the complex challenge of preserving the natural environment while simultaneously promoting development to meet the basic needs of humanity. With the adoption of globalization trade policies were liberalized, which caused further environmental destruction. Many problems resulted in this area of discussion, with regard to the intricate linkages between human rights and environmental decay. In spite of the tussle between human rights and environment protection one thing is ample clear that mankind is part of nature and separation of interests of human beings and the environment is quite difficult because human requires air, water and food in order to survive but on the hand contamination, pollution or destruction of these elements poses a direct threat to health, shelter, food and wellbeing of human life. In fact human right and environment go hand by hand because the degradation of the environment violates numerous well-recognized human rights. This is the fundamental principle that no life is possible without some level of healthful environment. Just because of this it can be averred that the right to environment is a condition precedent to all other human rights but at the same time the basis for a right to a healthful environment.

\section{REFRENCES}

1. www.iisd.ca > MEA Bulletin, accessed on 1.10.2019 at 12:00 pm

2. http://www.unep.org/environmentalgovernance/Events/HumanRightsandEnv ironment/tabid/2046/language/en-US/Default.aspx, accessed on 4.10.2019 at 4:07 pm

3. http://www.nliu.com/new/Art8.pdf, accessed on 2.10.2019 at 3:05 pm

4. Environmental Movement, Encyclopedia of Sustainable Development, at http://www.ac.uk/esd/Earth/Environmental-Movement.html. , accessed on 1.10.2019 at 2:00 pm

5. http://www.foei.org/en/what-we-do/solidarity-work/environmental-rights- are-human-rights, accessed on 1.10 .2019 at $1: 00 \mathrm{pm}$ 